\title{
Research on Earnings Management from the Perspective of Innovation and Market Competition
}

\author{
Ying Wang ${ }^{1, a}$ \\ ${ }^{1}$ College of Economics and Management, Zhoukou Normal University, Zhoukou, Henan, China \\ Zip code 466000 \\ awy1835@yeah.net
}

Keywords: Earnings management; Market competition; Governance effect; Innovation competitiveness

\begin{abstract}
Based on the empirical evidence of Chinese listed companies, this paper examines the relationship between earnings management and market competition. The study found that the market competition has a significant effect on the positive earnings management, the stronger the market competition is, the lower the level of earnings management. The relationship between negative earnings management and the market competition is the opposite, the stronger the market competition, the higher the negative earnings management. The study also found that, for companies with a strong innovation competitiveness, market competition has a stronger governance effect on earnings management. For companies that are not firm in innovation competitiveness, market competition has contributed to earnings management.
\end{abstract}

\section{Introduction}

In recent years, the relationship between market competition and earnings management has attracted the attention of scholars both at home and abroad. Scholars believe that the competition to improve the degree of the information asymmetry, which can objectively evaluate the manager (Holmstrom 1982; Nalebuff and Stiglitz, 1983), the competition can increase the information content of earnings, enable managers to provide information content of financial report higher, thereby reducing the degree of earnings management. Marciukaityte and Park (2009) shows that the higher the degree of product market competition is, the lower the degree of earnings management is. Dalia and Park (2009)found that the market competition weaken the impact of agency problems through the reduction of misleading earnings management and improvement the quality of earnings information. In the fierce competitive industry, the company engage less in earnings management, weaken degree of information asymmetry between the management of the company and other market information to users. In these industry, analyst earnings forecast error is smaller and smaller deviation illustrate this problem. In the fierce competitive industry, information content of stock price is high, once know the company has misleading positive earnings management,the stock market will make more severe punishment, leading to a long-term weakening performance of the stock market. Anyway, their studies show market competition is to improve financial reporting accuracy and effective mechanism for lowering the degree of information asymmetry of market, and low cost of the market competition mechanism, is far less than the government regulation and corporate governance. Balakrishman and Cohen (2011) shows that market competition is the effective mechanism of corporate executives constraints. They examined the positives influence of market competition on the financial accounting information false, found that market competition is 
binding on the management of false accounting information. On the one hand, in weak market competition industry, product market competition play the role of restraint mechanism; on the other hand, in the strong product market competition industry, market competition induced management not to maximize the interests of shareholders. Datta (2013) found that the product market pricing power is weak, the company can manipulate the high profit, their research add a new perspective.for understanding the transparency and credibility of the company's financial statements.

\section{Research background and research hypothesis}

In recent years, Chinese economy is going through a transitional development, in the top-down peoples innovation under the guidance of the principle, each industry is experiencing industrial upgrading, removing excess capacity and enhancing the innovation competence, which is the efficient path to market competition. Therefore, under the new economic situation and the more efficient market competition, the market competition should have a certain control effect on earnings management.

Based on the above discussion, we put forward the following expectations and set up model (1) and model (2):

Hypothesis 1 (a): market competition has the effect of external governance to the positive earnings management, the stronger the market competition, the lower the level of the company's positive earnings management.

If the hypothesis was established, the model (1) in the a 1 should be significantly positive.

Hypothesis 1 (b): the market competition has a negative effect on the negative earnings management, the stronger the market competition, the higher the company's negative earnings management level.

If the hypothesis was established, the model (2) in the a 1 should be significantly negative.

The level of innovation ability will determine future competition ability of the enterprise, and an enterprise has strong innovation and competitiveness ability, will has less pressure to face the market, management will not implement financial earnings management behavior for their own interests and professional development needs. Management will have a stronger incentive to implement financial earnings management in the face of greater operating pressure(Shleifer, 2004). On the other hand, in the fierce competition industry, with strong innovation and competitiveness ability, because of the information disclosureleading little threat from competitors, enterprises need mot through the earnings management deliberately obscured the true state of business information. Conversely, because of the information disclosure bring the threat of competitors is large, the enterprise will in order to cope with competition to cover up the real operating conditions and to keep a high degree of information asymmetry with the outside world (verrecchia, 1983; fan and Wong, 2002). Therefore, for thecompany with strong innovation and competitiveness ability,the stronger the market competition is, the lower the level of earnings management is. And if innovative competitiveness ability is not strong, the stronger the market competition, the higher the level of earnings management.

Based on the above discussion, we propose the following model (3):

Hypothesis 2 (a): a firm with a firm innovative competitiveness, market competition has a more significant governance effect on earnings management, and market competition has a significant positive correlation with the level of earnings management.

If the hypothesis was established, the model (3) should be significantly positive in the a 2 .

Hypothesis 2 (b): the innovation of the enterprise is not stable, the market competition has a more significant negative governance effect on earnings management, market competition and the 
company's earnings management level is significantly negative correlation.

If the hypothesis was established, the model (3) in the regression of the a 2 should be significantly negative.

\section{Research design and variable description}

The external governance effect of market competition on Earnings Management -- Based on positive earnings management and negative earnings management

In the existing literature, market competition as an external governance mechanism, probably has the company governance effect (Holmstrom, 1982; Nalebuff and Stiglitz, 1983), the level of earnings management should also be in the control range (Marciukaityte and park, a 2009), Zhou Xiafei (2014) methods for reference, this paper examines market competition on earnings management of external governance effects, not the same with the previous studies, this thesis is divided into positive earnings management and negative earnings management. The basic model is set as follows:

$$
\begin{aligned}
& \text { PODA }=\alpha_{0}+\alpha_{1} \text { Competition }+\alpha_{2} \text { Growth }+\alpha_{3} \mathrm{MTB}+\alpha_{4} \operatorname{Size}+\alpha_{5} \text { Lev }+\sum \gamma_{i} \text { Control }_{i}(\text { 模型1) } \\
& \mathrm{NEDA}=\alpha_{0}+\alpha_{1} \text { Competition }+\alpha_{2} \text { Growth }+\alpha_{3} \mathrm{MTB}+\alpha_{4} \operatorname{Size}+\alpha_{5} \operatorname{Lev}+\sum \gamma_{i} \text { Control }_{i}(\text { 模型 } 2)
\end{aligned}
$$

In the model, the PODA represents forward earnings management, when the discretionary accrual is positive, the value is 1 , otherwise the value is 0 . NEDA on behalf of the negative earnings management, when the discretionary accrual is negative value 1 , otherwise the value of 0 .

We use a modified Jones model for the performance ratio of ROA to estimate the sample enterprise's discretionary accrual.

Competition alternative variables is selected by the number of Companies in the industry. According to the research of Porter (1980), the number of enterprises in the industry is one of the important factors that affect the degree of competition in the industry, the more the number of entrepreneurs in the industry, the higher the degree of competition. Reference Cremers et al. (2007) and Balakrishnan and Cohen (2011) approach,in this paper, the number of sample entrepreneurs a year within a specific industry and reciprocal $(1 / \mathrm{N})$ as an alternative variable of the degree of competition in the industry.

Other variables are set as follows: the main business income growth rate of Growth; market book value ratio MTB; scale Size, the total assets of the logarithm; leverage ratio Lev, the ratio of long-term liabilities to total assets.

2.Earnings management, market competition and innovation competitiveness

Once the enterprise has a strong innovation competitiveness, the pressure of its business and competitors reducing at the same time, from the source to curb the level of earnings management. This paper, based on the new perspective of innovation competitiveness, tests the governance effect of market competition on the level of earnings management, which is different from the previous studies at home and abroad. The model is established as follows:

$$
\begin{aligned}
& \text { ABSDA }=\alpha_{0}+\alpha_{1} \text { Competition }+\alpha_{2} \text { Competition } * \text { Innocompetitiveness }+\alpha_{3} \text { Innocompetitiveness }+ \\
& \alpha_{4} \text { Growth }+\alpha_{5} \mathrm{MTB}+\alpha_{6} \text { Size }+\alpha_{7} \text { Lev }+\sum \gamma_{i} \text { Control }_{i}(\text { 模型3 })
\end{aligned}
$$

ABSDA is the absolute value of the discretionary accrual.Competition, Growth, MTB, Size, Lev are same with the above.

Innocompetitiveness on behalf of innovative competitiveness, the enterprise has a competitive value of innovation is 1 , does not have the value of innovation competitiveness is 0 . Enterprise core 
competitiveness comes from two aspects, one is the sustainable profitability of the enterprise, the two is the enterprise innovation can bring sustained profitability. In view of this, as research and development expenses accounted for more than 0.005 of the main business revenue and earnings growing over the previous year, enterprises is defined as having the value of innovation competitiveness. innovation competitiveness is divided into stable and unstable parts.if the R \& D expenditure to total net profit ratio is lower, the group said with stable innovation competitiveness (regression1), The rest is defined as unstable group (regression2).

\section{Empirical research results and analysis}

This paper selected the sample interval for the 2013 -2014, excluding the missing variables of the sample firms, and ultimately get 4978 observations from Chinese stock market. In this paper, the data processing and subsequent empirical analysis using spss22 software.

(1) The governance effect of market competition on earnings management -- Based on positive earnings management and negative earnings management

In the table 1 model (1) logistic regression $\alpha 1$ was significantly positive, assuming that 1 (a) was established. The market competition of positive earnings management with external governance effect, market competition more strong, positive earnings management level lower, this and (Marciukaityte and park, 2009; Balakrishman and Cohen, 2011) research results of phase echo. In the more competitive industries, the profit margin is relatively low, at this time enterprises through the manipulation of profits to improve the pressure of individual enterprises profit margins smaller, which leads to a lower level of positive earnings management.

In the table 1 model (2) logistic regression $\alpha 1$ was significantly negative. Hypothesis 1 (b) was established. That is, the market competition has a negative effect on the negative earnings management, the stronger the market competition, the higher the company's negative earnings management level. In the fierce competition industry, information dissymmetry is used to deal with the pressure of competition in the industry, to meet the industry generally low profit margin, engaged in negative earnings management, resulting in higher level of negative earnings management. 
Table1 Governance effect of market competition on Earnings Management (full sample)

\begin{tabular}{|c|c|c|c|c|c|c|}
\hline & \multicolumn{3}{|c|}{ P0DA（Mode11） } & \multicolumn{3}{|c|}{ NEDA (Mode12) } \\
\hline & B & Wald & Significant & B & Wald & Significant \\
\hline Competition & 1.877 & 3.904 & .050 & -.825 & 3.980 & .049 \\
\hline Growth & .000 & .002 & .962 & .000 & .041 & .840 \\
\hline MTB & -.026 & 1.231 & .267 & .023 & 1.070 & .301 \\
\hline Size & -.134 & 3.583 & .055 & .194 & 4.936 & .026 \\
\hline Lev & 1.114 & .950 & .330 & -1.955 & 2.483 & .115 \\
\hline Annual effect & $\begin{array}{l}\text { contro } \\
\text { I }\end{array}$ & control & control & control & control & control \\
\hline Industry effect & $\begin{array}{l}\text { contro } \\
\text { I }\end{array}$ & control & control & control & control & control \\
\hline constant & 2.775 & 3.490 & .060 & -4.126 & 4.437 & .035 \\
\hline
\end{tabular}

(2) Earnings management, market competition and innovation competitiveness

Model (3) in the regression 1 of the $\alpha 2$ should be significantly positive, assuming that 2 (a) was established. To a stable and innovative competitiveness of enterprises, market competition has a more significant governance effect on earnings management, with the market competition becomes stronger, the company's earnings management level is reduced more. Companies with a firm and innovative competitiveness, the competition is efficient market competition, efficient market competition for earnings management should play an external governance effect. Therefore, the stronger the market competition is, the lower the earnings management level is. This is also a result of the smaller market pressures faced by the management and the smaller competitor threat caused by information disclosure.

Model (3) in the regression 2 of $\alpha 2$ should be significantly negative, assuming that 2 (b) was established. To a enterprise of unstable innovative competitiveness, the market competition has a more significant negative governance effect on earnings management, with the market competition becomes stronger, the company's earnings management level is increased more. When innovation competitiveness is not strong, although research and development spending has brought a corresponding profit growth, but due to the $\mathrm{R} \& \mathrm{D}$ expenditures accounted for a large proportion of net profit, resulting in less pressure load capacity. Information disclosure led to the joint role of competitors and market pressures, resulting in a more competitive industry, the management has a stronger incentive to conduct earnings management. 
Table2 Earnings management, market competition and innovation competitiveness

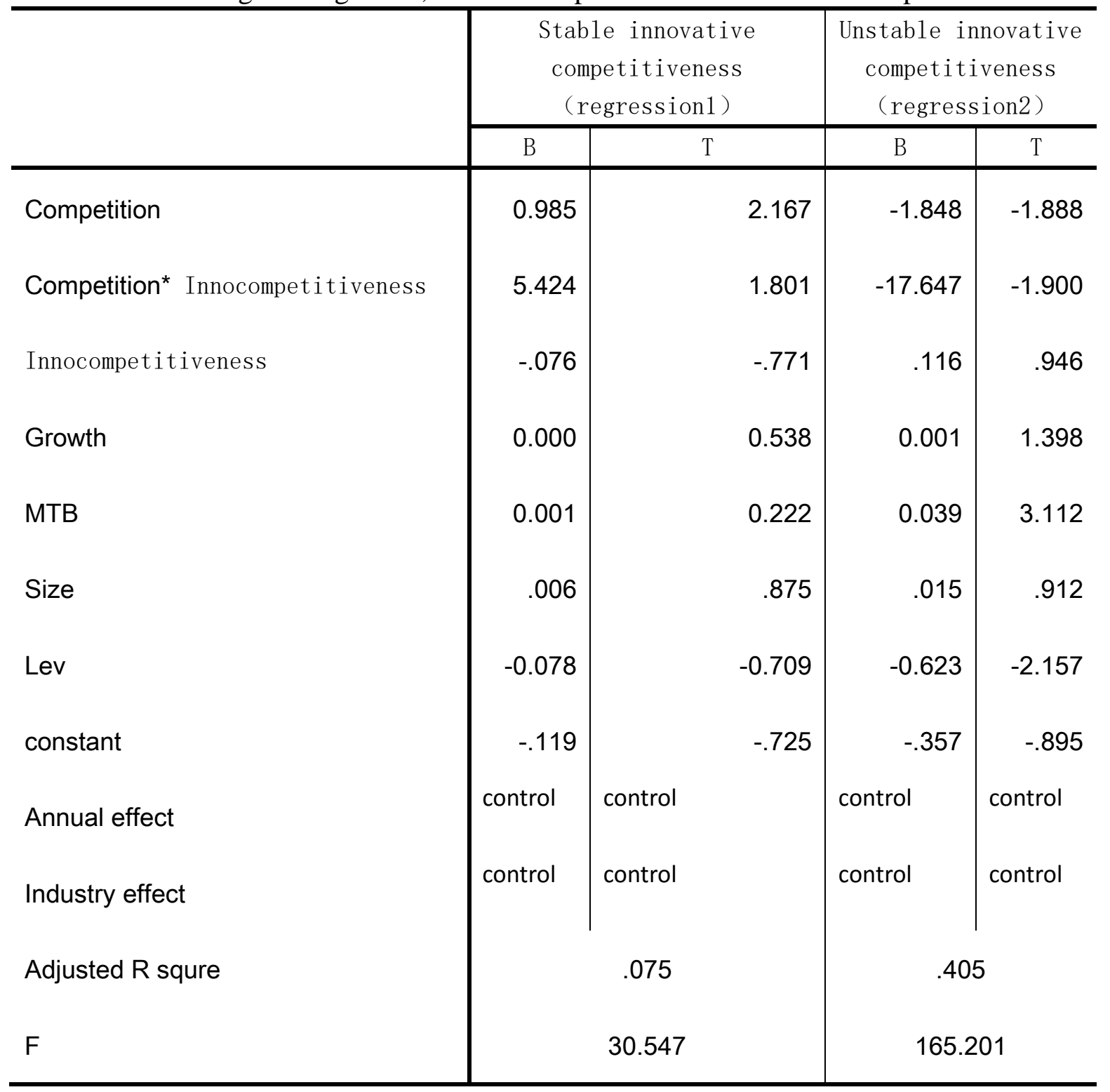

\section{Conclusion}

From two aspects of positive earnings management and negative earnings management, this paper examines the governance effect of market competition on earnings management, and examines the relationship between earnings management, market competition and innovation competitiveness. By using the data of Chinese listing Corporation in 2013-2014, the research finds that: the market competition has a significant governance effect on the positive earnings management, and has a significant negative effect on the negative earnings management. To firms with stable innovative competitiveness, market competition has stronger governance effect on earnings management, and to firm with unstable innovative competitiveness, the market competition has a stronger negative effect on earnings management.

\section{Acknowledgements}

Zhoukou Normal University in 2015 the first batch of high level scientific research personnel started funding the project "Research on Earnings Management -- Based on the governance mechanism of market competition perspective" (project number: zknuc2015116) 


\section{References:}

[1] Allen, F. , and D. Gale. 2000. Corporate Governance and Competition. In Corporate Governance: Theoretical and Empirical Perspectives. Cambridge University Press

[2] Cremers, K. , V. Nair, and U. Peyer. 2007. Takeover Defenses and Competition. ICF Working Paper, No. 07-02. Yale University 